\section{SEVENTY YEARS AGO}

\author{
NATURE, vol. I, March 3, I870
}

\section{Natural Science at Cambridge}

The Rev. T. G. Bonney, the geologist, concluding an article on this subject, writes: "I may venture to express my conviction, that the coldness and even dislike with which the study of Natural Science was once regarded here is rapidly passing away, that the number of earnest students in the various branches is annually increasing, and that the University is fully alive to the wants of the age; so that, while she can never neglect or forget those old paths of Classics and Mathematics in which many of her sons have won an almost world-wide reputation, she will heartily welcome, and will regard with no less pride, all who are among the followers of sciences of a more recent date."

\section{Measurement of Geological Time}

Alfred Russel Wallace presents the second and concluding article on this topic. He discusses, in particular, the effects of denudation as shown by Geikie's investigations. Surveying the estimates made by 'Tylor, Croll, Geikie and Lyell, he deduces a scale of geological time ranging from 24,000,000 years for the beginning of the Cambrian, to $2,000,000$ years for the beginning of the Lower Miocene. $\mathrm{He}$ continues: "These figures will seem very small to some geologists who have been accustomed to speak of 'millions' as small matters; . . . Taking Sir William 'Thomson's allowance of a hundred million years for the time during which the earth can have been fit for life, it yet allows Mr. Darwin, for the process of development from the primordial germ, three times as many years anterior to the Cambrian epoch as have elapsed since that date, an amount of time which, I believe, will fully satisfy him, by whatever scale we may measure it."

\section{Industrial Use of an Electric Motor}

"For many years it has been a query whether the electric current might not be brought so far under man's control as to take the place of steam as a motor for machinery, and success has at last crowned the persevering efforts of scientists. At the last exhibition of the American Institute, there was seen an elliptic lock-stitch sewing machine, driven by a small electric engine which might easily be put into a common hat box. . . . The use of this motor, if it becomes general, cannot fail to prove of the utmost benefit to ladies, especially to machine operators, as it does away entirely with the necessity for using the feet, as is now the case, and must be highly conducive to the health of females, who suffer from many diseases that are generated by the constant strain on the pedal and limb muscles. The inventor of the engine in question is Charles Gaume."

"Mr. E. RAy Lankester has been elected by examination to the Radcliffe Travelling Fellowship at Oxford."

THE American Gaslight Journal and Chemical Repertory states that Professor Loomis, who claims to have discovered a way to transmit messages by electrical air currents without the aid of wires, wants to be appointed Consul to some European port, that he may experiment on the summit of Mont Blanc.

\section{APPOINTMENTS VACANT}

Appicications are invited for the following appointments on or before the dates mentioned:

Two Teachers of ENgLish in Timisoara and Iasi-The British Council, 3 Hanover Street, W.1 (quoting 'Rumania') (March 9).

TEChNioal Assistant in the Mechanical and Electrical Engineer's Section-The Engineer and Manager, Waterworks Department, Town Hall, Manchester 2 (March 16).

ONE SENIOR AsSistant and SIX Assistants for Evening Institutes in Egypt-The British Council, 3 Hanover Street, W.1 (quoting 'Egypt') (March 18).

Divisional Engineer (WIREless) for the Malayan Postal Service -The Crown Agents for the Colonies, 4 Millbank, S.W.1 (quoting M/9134).

\section{REPORTS AND OTHER PUBLICATIONS}

(not included in the monthly Books Supplement)

\section{Great Britain and Ireland}

Department of Scientiflc and Industrial Research. Methods for the Detection of Toxic Gases in Industry, Leaflet No. 7 : Carbon Monoxide. Pp. iv $+9+2$ plates. (London: H.M. Stationery Office.) 18. $6 d$. Philosophical Transactions of the Royal Society of London. Series A : Mathematical and Physical Sciences. No. 793, Vol. 238: Stress Functions for a Plate containing Groups of Circular Holes. By Dr. R. C. J. Howland and Dr. R. C. Knight. Pp. 357-392. 6s. No. 794 Vol. 238: Crystallographic Studies of Meteoric Iron. By J. Young. Pp. 383-422. 68. 6d. No. 795, Vol. 238: The Asymptotic Expansion of Integral Functions defined by Taylor Series. By Prof. E. M. Wright. Pp. 423-452. 48. (London: Cambridge University Press.) [142
University of London Institute of Archæology. Geochronological Table No. 1: An Attempted Correlation of Quaternary Geology, Pei. (Occasional Paper No. 2) Pp. 16+2 tables. (London: University of London Institute of Archæology.) 2s. $6 d$.

The Carnegie Trust for the Universities of Scotland Thirty-eighth The Carnegie Trust for the Universities of Scotland. Thirty-eighth Annual Report (for the Year 1938-39) submitted by the Executive Committee to the Trustees on 12th February 1940 . Pp. iv +90 .
(Edinburgh: Carnegie Trust for the Universities of Scotland.) $[142$ (Edinburgh : Carnegie Trust for the Universities of Scotiand.) their Lay-out and Statistical Analysis. By Dr. John Wishart. Pp. 36. (Cambridge: School of Agriculture.) $28,6 d$.

\section{Other Countries}

Imperial Council of Agricultural Research, India. Scientific Monograph No. 13: Further Observations on Anatomical Deviations in the Ox and Notes on Certain Anatomical Freaks. By $\mathbf{H}$. N. Chelva Ayyangar. Pp. vi $+42+31$ plates. (Delhi : Manager of Publications.) Ayyangar. Pp. vi $+42+31$ plates. (Delhi : Manager of Publications.)
2.8 rupees: 48 . Reports of the Biochemical Research Foundation of the Franklin
Rupees : 48 . Institute. Vol. 5, 1938-1939. Pp. vii +42 papers. (Philadelphia Franklin Institute.) Transactions of the National Institute of Sciences of India. Vol. 2, No. 2: Changes brought in Colloids by Dialysis. By Dr. B. N. Desai and P. M. Barve. Pṕ. 39-68. (Calcutta: National Institute

Tanganyika Territory: Department of Lands and Mines, GeoTanganvika Territory: Department of Lands and Mines, Geo-
logical Division. Bulletin No. 12: The Kimberlite Province and logical Division. Bulletin No. 12: The Kimberlite Province and Associated Diamond Deposits of Tanganyika Territory By Dr.
G. J. Williams. Pp. $41+3$ plates. (Dar es Salaam: Government G. J. Williams. Pp. $41+3$ plates. (Dar es Salaam: Government
Printer.) 3s.

Indian Forest Records (New Series). Entomology, Vol. 5, Nos. 4, 5, 6: On the Biology of the Parasites of the Teak Defoliators, Hapalia machoeralis Walk. (Pyralides) and Hybloea puera Cram. (Hyblæidæ) in Burma, by P. F. Garthwaite and M. H. Desai ; Further Notes on the Biology of Parasites of Teak Defoliators in India, by C. F. C. Beeson and S. N. Chatterjee; On the Biology and Morpho logy of Apanteles machoeralis Wlkn.' (Braconidæ, Hymenopt.), by P. N. Chatterjee. Pp. ii $+309+396$. (Delhi : Manager of Publications.) 2 rupees; $3 s$.

Dominion of Canada: Department of Transport, Air Services Branch: Division of Meteorological Services of Canada. Canadian Polar Year Expeditions, 1932-33. Terrestrial Magnetism, EarthCurrents, Aurora Borealis: Chesterfleld Inlet, Meanook, Saskatoon. Vol. 2. Pp. 185. (Ottawa : King's Printer.)

Instituto Nacional de Tecnologia (Ministerio do Trabalho, Industria e Comercio). O controle de concreto numa construção. Pelo Albert Pastor de Oliviera. Pp. 21. Dosagem racional em tubulaşão d concreto. Pelo Adhemar da Cunha Fonseca. Pp. 52. (Rio de Janeiro:
Instituto Nacional de Tecnologia.)

\section{Catalogues, etc.}

The Basic Cause of Hl-Health. By K. Cookson. Pp. 20. (Slough: Cooksonisers (Slough), Ltd.)

Pyelectan for Intravenous Pyelography. Pp. 2. Kapilon for Vitamin K Therapy. Pp. 2. (Greenford: Glaxo Laboratories, Ltd.) Industrial Thermometers, Hygrometers, Manometers. (List No. 64i.) Pp. vi +64. (London: C. F. Casella and Co., Ltd.) 